Tsisaruk I. V. Analysis of the results of experimental research of professional development of the future teacher of labor education and technologies in technologies. Journal of Education, Health and Sport. 2020;10(3):295-301. eISSN 2391-8306. DOI http://dx.doi.org/10.12775/JEHS.2020.10.03.031

https://apcz.umk.pl/czasopisma/index.php/JEHS/article/view/JEHS.2020.10.03.031

https://zenodo.org/record/4476826

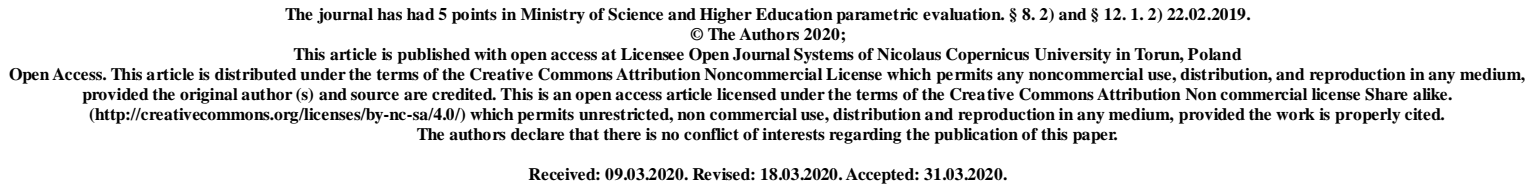

UDC 378: 373.091.12.011.3-051

\title{
ANALYSIS OF THE RESULTS OF EXPERIMENTAL RESEARCH OF PROFESSIONAL DEVELOPMENT OF THE FUTURE TEACHER OF LABOR EDUCATION AND TECHNOLOGIES IN TECHNOLOGIES
}

\author{
I. V. Tsisaruk
}

Kremenets Regional Humanitarian and Pedagogical Academy named after Taras Shevchenko, Kremenets, Ukraine

Assistant of the Department of Theory and Methods of Technical Education and Technologies https://orcid.org/0000-0002-7285-9055

\section{Abstract}

The article is devoted to the analysis of results of experimental research of professional development of future teachers of technical education and technologies in the process of independent work. The dynamics of levels of professional development after the formative stage of experimental research is shown.

Keywords: professional development; future teachers; pedagogical conditions; ascertaining stage; formative stage; experimental research.

Анотація. Стаття присвячена висвітленню аналізу результатів експериментального дослідження професійного розвитку майбутніх учителів трудового навчання та технологій у процесі самостійної роботи. Показано динаміку рівнів 
професійного розвитку після проведення формувального етапу експериментального дослідження.

Ключові слова: професійний розвиток; майбутні вчителі; педагогічні умови; констатувальний етап; формувальний етап; експериментальне дослідження.

Formulation of the problem. The main principle of modern education is its continuity. The concept of continuing education presents it as a process of purposeful development of socio-cultural experience. «Lifelong learning»-a set of formal and informal types of education, which allows everyone at any stage of his life to acquire the necessary knowledge, skills, abilities. Social transformations have contributed to the change of values of education in society - today the constant renewal of knowledge is becoming a major factor in the competitiveness of both - an individual and a state as a whole. The Bologna Declaration focuses on introduction of significant volumes and various types of self-study in the training of future professionals who are required to have thorough knowledge, skills and abilities to respond quickly and efficiently to changes in the professional environment, society, the ability to learn independently throughout life. These priorities determine requirements for the formation of professional and self-educational competencies of future teachers of technical education and technology [1].

Analysis of recent research and publications. Analysis of a set of scientific and pedagogical and information sources on the problems of professional training of future teachers of technical education and technology shows that the study of its individual aspects was given considerable attention by such scientists as A. Androschuk, I. Androschuk, O. Kobernyk, M. Korets, E. Kulyk , M. Kurach, G. Levchenko, V. Madzigon, L. Orshansky, V. Sidorenko, V. Steshenko, A. Tereshchuk, G. Tereshchuk, V. Tymenko, V. Tytarenko, O. Torubara, D. Thorzhevsky, A Tsyna, S. Yashchuk, etc., while the issues of professional development of future teacher of technical education and technologies in a process of independent work are only indirectly covered in the publications: G. Makarova, L. Orshansky, I. Vechery, V. Sipaylo, I. Yaremchuk etc.

The purpose of the article is to analyze the results of experimental verification of effectiveness of a set of pedagogical activities in the process of professional training of future teachers of labor education and technology in a process of independent work.

Presentation of main material. In the course of the research a hypothesis was put forward, which was that professional development of a future teacher of technical education 
and technology in the process of independent work becomes effective if the following pedagogical conditions are kept:

- motivated training of a future teacher of technical education and technologies of strategies of independent work with maintenance of an individual educational trajectory at a stage of their professional and personal development;

- realization of educational potential of modern practice-oriented technologies of independent work taking into account domestic and foreign achievements, in the unity of pedagogical innovation and historically tested experience, based on Ukrainian folk crafts and decorative and applied arts;

- scientific and methodological support of the process of professional development of a future teacher on the basis of humanization of interaction «teacher - student», «student teacher», «student - student», «colleague - colleague»; means of organizing, leading and managing independent work on the basis of physilitic communication and supervisory assistance in overcoming difficulties to achieve success;

- programming of portfolio of personal and professional development by a future teacher of labor training and technology for successful self-realization and an ability to continue learning with lifelong autonomy skills, successful career start and professional growth in the future profession, etc [2].

Verification of effectiveness of the proposed pedagogical conditions was carried out according to certain criteria: value-motivational, cognitive-technological, operational-activity, evaluation-reflexive. Necessary methods (questionnaires, creative projects) were selected for each criterion, according to its indicators, the processing of which allowed to determine the state of levels of professional development of future teachers of technical education and technologies at the ascertaining stage of experimental research. The generalized data of results of a statement stage are resulted in table 1.

Table 1 shows that the vast majority of respondents are diagnosed with an average level of manifestation of the studied components (ranging from $24,59 \%$ to 40,16\%). The initial level is typical for about a third of respondents $(28,69 \%-42,62 \%)$. Manifestations of sufficient level $-18,85 \%-34,43 \%$ of students, high level of component composition of the studied phenomenon was $9.84 \%-14.75 \%$.

Thus, content and strategy of further research will be such factors of educational process of professional training of future teachers of labor training and technology, which will help to improve professional development of future professionals. 
Table 1

The results of ascertaining stage of the pedagogical experiment

\begin{tabular}{|l|c|c|c|c|c|c|c|c|}
\hline \multirow{2}{*}{$\begin{array}{l}\text { The name of } \\
\text { the criterion }\end{array}$} & \multicolumn{2}{|c|}{ Initial level } & \multicolumn{2}{c|}{ Average } & \multicolumn{2}{c|}{ Sufficient level } & \multicolumn{2}{|c|}{ High level } \\
\cline { 2 - 9 } & $\begin{array}{c}\text { KG } \\
\text { (in\%) }\end{array}$ & $\begin{array}{c}\text { EG } \\
\text { (in\%) }\end{array}$ & $\begin{array}{c}\text { KG } \\
\text { (in\%) }\end{array}$ & $\begin{array}{c}\text { EG } \\
\text { (in\%) }\end{array}$ & $\begin{array}{c}\text { KG } \\
\text { (in\%) }\end{array}$ & $\begin{array}{c}\text { EG } \\
\text { (in\%) }\end{array}$ & $\begin{array}{c}\text { KG } \\
\text { (in\%) }\end{array}$ & $\begin{array}{c}\text { EG } \\
\text { (in\%) }\end{array}$ \\
\hline $\begin{array}{l}\text { Value- } \\
\text { motivational }\end{array}$ & 32,22 & 29,56 & 22,8 & 25,26 & 35,56 & 34,95 & 9,42 & 10,23 \\
\hline $\begin{array}{l}\text { Cognitive- } \\
\text { technological }\end{array}$ & 33,34 & 33,87 & 35,00 & 27,42 & 18,89 & 22,58 & 12,78 & 16,13 \\
\hline $\begin{array}{l}\text { Operational } \\
\text { activity }\end{array}$ & 43,89 & 41,4 & 27,22 & 27,96 & 18,33 & 19,36 & 10,56 & 11,29 \\
\hline $\begin{array}{l}\text { Evaluative- } \\
\text { reflexive }\end{array}$ & 29,45 & 26,89 & 39,44 & 40,32 & 21,67 & 21,5 & 9,34 & 11,29 \\
\hline $\begin{array}{l}\text { General } \\
\text { level }\end{array}$ & $\mathbf{3 4 , 7 3}$ & $\mathbf{3 2 , 9 3}$ & $\mathbf{3 1 , 1 2}$ & $\mathbf{3 0 , 2 4}$ & $\mathbf{2 3 , 6 1}$ & $\mathbf{1 9 , 8 5}$ & $\mathbf{1 0 , 5 3}$ & $\mathbf{1 2 , 2 4}$ \\
\hline
\end{tabular}

Based on a set of pedagogical conditions, we have developed structural and functional model and interactive development program for professional development of future teachers of technical education and technology (IRPPR), which includes step-by-step method of improving professional development (forms, methods, technologies, tools, etc). The purpose of the formative experiment was to determine the implementation and verification of effectiveness of pedagogical conditions and structural-functional model. To determine effectiveness of the implemented pedagogical conditions aimed at the gradual development of professional-value, cognitive-activity, design-technological and regulatory-reflexive components, after the formative stage of the experiment we conducted repeated questionnaires and testing of students of control and experimental groups, as well as carried out mathematical processing of results. We selected a control group (CG) of 60 students and an experimental (EG) - 62 students. Table 2 offers generalized diagnostic results at four levels after the molding phase of the experiment.

Table 2

Generalized data of the state of professional development of future teachers of technical education and technology after the experiment

\begin{tabular}{|l|c|c|c|c|}
\hline \multirow{2}{*}{ Level } & \multicolumn{2}{|c|}{ CG (60 people - 100\%) } & \multicolumn{2}{c|}{ EG (62 - 100\%) } \\
\cline { 2 - 5 } & Number of & \% & Number of & \% \\
\hline Initial & 12 & 20,00 & 7 & 11,29 \\
\hline Average & 22 & 36,67 & 16 & 25,81 \\
\hline Sufficient & 17 & 28,33 & 24 & 38,71 \\
\hline High & 9 & 15,00 & 15 & 24,19 \\
\hline
\end{tabular}


For better perception of the results of control phase of the study, Diagram 1 shows comparative data on the state of formation of professional development of future teachers of technical education and technologies of CG and EG.

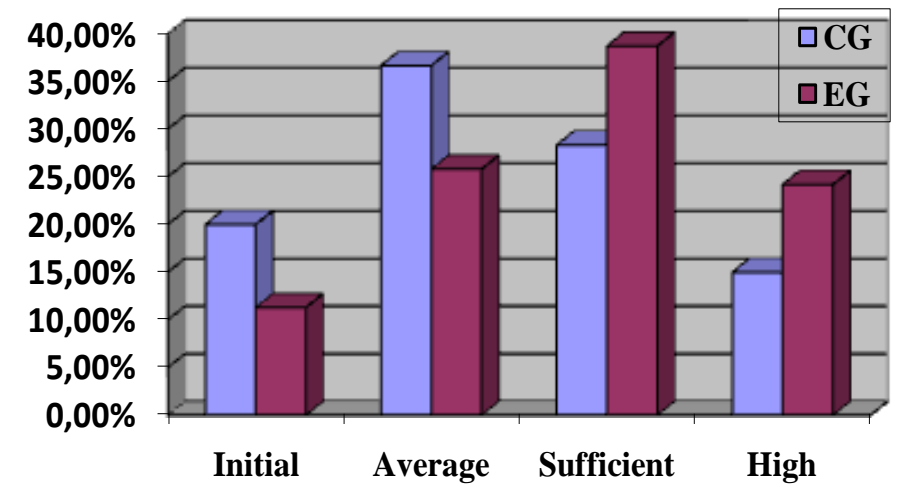

Diagram 1. Generalized data of the state of the level of professional development of future teachers of labor training and technology after the experiment (in \%)

To fully understand the dynamics of the levels of professional development of future teachers of technical education and technology, we reflect the results of the ascertaining and control stages in table 3:

Table 3

Generalized data of the analysis of level of formation of professional development of future teachers of labor training and technologies before and after the experiment

\begin{tabular}{|c|c|c|c|c|c|c|c|c|}
\hline \multirow{3}{*}{ Level } & \multicolumn{4}{|c|}{ CG (60 people - $100 \%)$} & \multicolumn{4}{|c|}{ EG (62 - 100\%) } \\
\hline & \multicolumn{2}{|c|}{ to the experiment } & \multicolumn{2}{|c|}{$\begin{array}{c}\text { after the } \\
\text { experiment }\end{array}$} & \multicolumn{2}{|c|}{ to the experiment } & \multicolumn{2}{|c|}{$\begin{array}{c}\text { after the } \\
\text { experiment }\end{array}$} \\
\hline & \begin{tabular}{|c|}
$\begin{array}{c}\text { Number } \\
\text { of }\end{array}$ \\
\end{tabular} & $\%$ & Number of & $\%$ & Number of & $\%$ & Number of & $\%$ \\
\hline Initial & 21 & 35,00 & 12 & 20,00 & 20 & 32,26 & 7 & 11,29 \\
\hline Average & 19 & 31,67 & 22 & 36,67 & 19 & 30,65 & 16 & 25,81 \\
\hline Sufficient & 14 & 23,33 & 17 & 28,33 & 15 & 24,19 & 24 & 38,71 \\
\hline High & 6 & 10,00 & 9 & 15,00 & 8 & 12,9 & 15 & 24,19 \\
\hline
\end{tabular}

Let's analyze final results of the experimental study, comparing the obtained data of observational and control stages. After the experiment, the indicators of the high level of professional development of future teachers of technical education and technology improved in CG from $10,00 \%$ to $15,00 \%$ and in $\mathrm{EG}$ - from $12,9 \%$ to $24,19 \%$, and indicators of sufficient level increased from $23,33 \%$ to $28,33 \%$ in CG and from 24,19 to $38,71 \%$ in EG. 
The results of the average level of formation in CG increased from $31,67 \%$ to $36,67 \%$, and in EG, on the contrary, decreased from $30,65 \%$ to $25,81 \%$. The initial level underwent the greatest positive changes: in CG it decreased from $35,00 \%$ to $20,00 \%$, and in EG - from $32,26 \%$ to $11,29 \%$.

Let's represent comparative results of $\mathrm{KG}$ and $\mathrm{EG}$ before and after carrying out experimental research by means of the diagram.

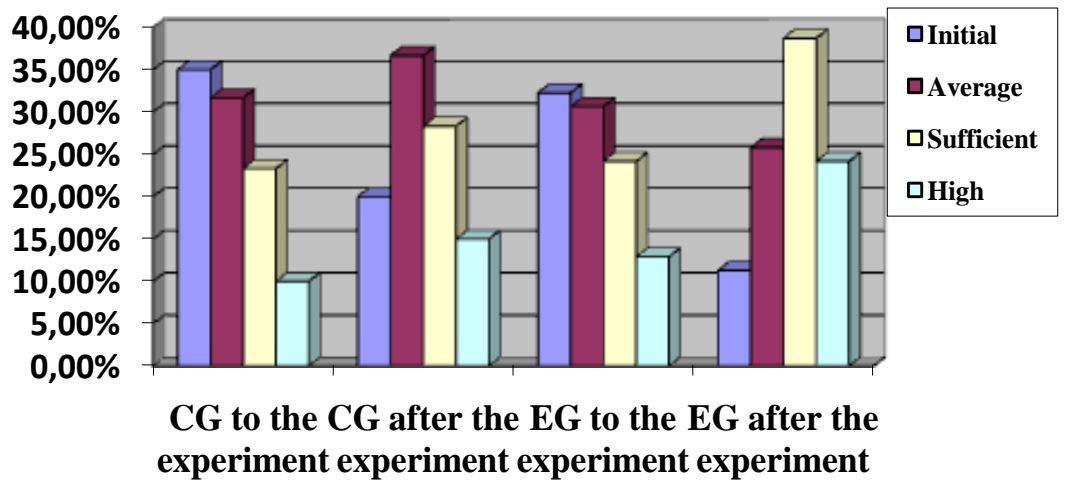

Diagram 2. Dynamics of levels of formation of professional development of future teachers of labor training and technologies before and after the experiment (\%)

The analysis of generalized data showed that professional training of future teachers of technical education and technologies with the use of the latest technologies of independent work is more effective, in comparison with the traditional system of education.

Conclusion. On basis of received experimental data we can draw a conclusion: with increase at levels of formation of indicators of professional-value, cognitive-activity, projecttechnological and regulatory-reflexive components at students, as the result of embodiment of a set of pedagogical actions in educational process, increases the level of professional development of future teachers of technical education and technology in the process of independent work.

\section{References}

1. Nikolaichuk I. V. (2011). Neobkhidnist nastupnosti ta samostiinoi roboty u protsesi pidhotovky maibutnoho vchytelia trudovoho navchannia. Pedahohichna teoriia i praktyka: zb. nauk. prats. Kyiv: KyMU, V. 2. S. 197-209.

2. Tsisaruk I. V. (2020). Pedahohichni umovy efektyvnosti profesiinoho rozvytku maibutnikh uchyteliv trudovoho navchannia ta tekhnolohii u protsesi samostiinoi roboty. Suchasni tekhnolohii pidhotovky maibutnikh uchyteliv trudovoho navchannia ta tekhnolohii, 
pedahohiv profesiinoi osvity $i$ fakhivtsiv obrazotvorchoho ta dekoratyvnoho mystetstva: teoriia, dosvid, problemy: zbirnyk naukovykh prats. Vinnytsia. Vyp. 2. S. 48-51. 